KS. TOMASZ JAKUBIAK

Papieski Wydział Teologiczny w Warszawie

Sekcja św. Jana Chrzciciela

\title{
CZY ZAWSZE PO UZYSKANIU INFORMACJI O MOŻLIWOŚCI POPEŁNIENIA PRZESTECSTWA NALEŻY WSZCZYNAĆ KARNE POSTĘPOWANIE SĄDOWE LUB ADMINISTRACYJNE DLA REALIZACJI SANKCJI KARNEJ?
}

Treść: Wstęp. - 1. Cel kary. - 2. Realizacja celów kary. - 3. Decyzja ordynariusza. - 4. Przedawnienie. - Podsumowanie.

\section{Wstęp}

Niejednokrotnie w ramach sprawowania władzy jurysdykcyjnej przez ordynariusza - w czasie zbierania informacji potrzebnych do wydania decyzji lub dekretu - okazuje się, że osoba, której akt władzy ma dotyczyć, dopuściła się czynu, za który prawo Kościoła przewiduje obligatoryjną karę. Przykładowo dzieje się tak, gdy ordynariusz potwierdza stan wolny osoby, która usiłowała zawrzeć małżeństwo bez dyspensy od formy kanonicznej w akatolickiej wspólnocie lub Kościele, albo też gdy stwierdza fakt chrztu dziecka rodziców katolickich, którzy oddali je do chrztu w religii akatolickiej. Zgodnie z decyzją najwyższego ustawodawcy, promulgowaną w kan. 1365 oraz $1366 \mathrm{KPK}^{1}$, osoby dopuszczające się powyższych przestępstw

\footnotetext{
${ }^{1}$ Skrót KPK oznacza: Codex Iuris Canonici auctoritate Ioannis Pauli PP. II promulgatus fontium adnotatione et indice analytico-alphabetico auctus. Liberia Editrice Vaticana 1989. Tłum. polskie: Kodeks prawa kanonicznego, przekład polski zatwierdzony przez Konferencję Episkopatu, Poznań 1984.
} 
powinny zostać ukarane w pierwszym przypadku - sprawiedliwą karą, w drugim - cenzurą bądź sprawiedliwą karąa ${ }^{2}$.

Życie dostarcza wielu sytuacji, w których sprawą publiczną jest fakt naruszenia ustawy karnej przez wiernego, i to nie tylko przy gromadzeniu dokumentów wymaganych przez prawo partykularne lub powszechne przed wydaniem zgody i dyspensy dotyczących szeroko rozumianych kwestii sakramentalnych. Śledząc programy telewizyjne i radiowe, czytając prasę lub przeglądając internet, jesteśmy świadkami znieważania religii oraz siania nienawiści do Kościoła czy też deklaracji zaprzeczających jakiejś prawdzie, w którą należy wierzyć wiarą boską i katolicką, lub odmowy uznania zwierzchnictwa Biskupa Rzymu oraz utrzymywania wspólnoty z członkami Kościoła uznającymi to zwierzchnictwo (por. kan. 751 KPK 1983). Katolicy dopuszczający się takich czynów również naruszają ustawę, do której dołączona jest sankcja karna ${ }^{3}$. Czynów, za popełnienie których ustawodawca przewiduje obligatoryjną sankcję karną, jest znacznie więcej.

W przywołanym kontekście konieczne jest ustalenie, czy zawsze po uzyskaniu informacji o możliwości popełnienia przestępstwa, za które ustawodawca przewiduje obligatoryjne wymierzenie kary (albo karę latae sententiae), należy wszczynać karne postępowanie sądowe - lub administracyjne - dla realizacji sankcji karnej.

\footnotetext{
${ }^{2}$ Kan. 1365 KPK: Winny zakazanego uczestnictwa w rzeczach świętych ma być ukarany sprawiedliwą karą.

Kan. 1366 KPK: Rodzice lub ich zastępujący, którzy oddają dzieci do chrztu lub na wychowanie w religii niekatolickiej, powinni być ukarani cenzurą lub inną sprawiedliwą karą.

${ }^{3}$ Kan. 1369 KPK: Kto w publicznym widowisku, w kazaniu, w rozpowszechnionym piśmie albo w inny sposób przy pomocy środków społecznego przekazu, wypowiada bluźnierstwo, poważnie narusza dobre obyczaje albo znieważa religię lub Kościół bądź wywołuje nienawiść lub pogardę, powinien być ukarany sprawiedliwą karą.

Kan. 1364 KPK: \$1. Odstępca od wiary, heretyk lub schizmatyk podlega ekskomunice wiążącej mocą samego prawa, przy zachowaniu przepisu kan. 194\$1, n. 2; duchowny może być ponadto ukarany karami, o których w kan. 1336\$1, n. 1-3.

\$2. Jeśli tego domaga się długotrwały upór lub wielkość zgorszenia, można dołączyć także inne kary, nie wyłączając wydalenia ze stanu duchownego.
} 


\section{Cel kary}

Ustawodawca w kan. 1341 KPK zamieścił przepis, zgodnie z którym: „ordynariusz dopiero wtedy powinien wszcząć postępowanie sądowe lub administracyjne celem wymierzenia lub deklaracji kary, gdy uznał, że ani braterskim upomnieniem, ani naganą, ani też innymi środkami pasterskiej troski nie można w sposób wystarczający naprawić zgorszenia, wyrównać naruszonej sprawiedliwości i doprowadzić do poprawy winnego". Zdaniem De Paolisa, kanon ten stanowi klucz do interpretacji prawa karnego w ogólności oraz norm dotyczących wymierzania kar w szczególności ${ }^{4}$. Wyraża on zamysł prawodawcy przyświecający reformie Kodeksu prawa kanonicznego ${ }^{5}$. Według wytycznych przyjętych w 1967 roku przez zgromadzenie Synodu Biskupów, nowoopracowane prawo Kościoła łacińskiego winno po reformie: popierać troskę duszpasterską, uwzględniać cnotę sprawiedliwości i miłości, odznaczać się umiarkowaniem, ludzkim podejściem. Zatem, normy zbyt surowe miały zostać odrzucone. Tam, gdzie nie zachodziła konieczność ścisłego przestrzegania prawa, ze względu na dobro publiczne i ogólną dyscyplinę kościelną, należało raczej posługiwać się zachętami i radami ${ }^{6}$.

Nie ma więc czemu się dziwić, że w myśl kan. 1341 KPK, nawet gdy przestępstwo zostanie popełnione - kiedy zostanie zweryfikowany fakt i okoliczności jego popełnienia oraz zostanie ustalona poczytalność przestępcy - można będzie mimo wszystko uniknąć procedury karnej, jeśli w jakiś inny sposób możliwe będzie doprowadzenie do zachowania kościelnej dyscypliny. Dzieje się tak dlatego, że inne są cele bezpośrednie i ostateczne karnej procedury kanonicznej. Chociaż bezpośrednim celem karnej procedury jest stwierdzenie lub nałożenie

\footnotetext{
${ }^{4}$ Por. V. De Paolis, The Application of Penalties, w: Exegetical Commentary on the Code of Canon Law, ed. Á. Marzoa, J. Miras, R. Rodríguez-Ocaña, English language ed. E. Caparros, P. Lagges, vol. IV/1, Montreal Chicago 2004, s. 364.

${ }^{5}$ Por. R. Sobański, Idee przewodnie nowego Kodeksu prawa kanonicznego, w: Duszpasterstwo w świetle nowego Kodeksu prawa kanonicznego, red. J. Syryjczyk, Warszawa 1985, s. 49.

${ }^{6}$ Por. Prefatio, w: KPK.
} 
kary, to jednak ostatecznym celem nie jest karanie, lecz osiągnięcie celów kary.

Zdaniem De Paolisa, cel kary jest potrójny. Jest nim: naprawienie zgorszenia, wyrównanie sprawiedliwości, poprawa przestępcy. Nie mogą one zostać zignorowane ${ }^{7}$. Jak zauważa Syryjczyk, kodeks z 1983 roku, w odróżnieniu do kodeksu Pio-Benedyktyńskiego, mówiąc o celach kary, na pierwszy plan nie przypadkowo wysuwał poprawę przestępcy, kładąc tym samym mocniejszy akcent na nią ${ }^{8}$. Na marginesie należy zauważyć, że kodeks z 1917 roku poprawę przestępcy zaliczał do celów drugorzędnych i ubocznych kary kanonicznej. Pierwszorzędnym celem był odwet. Jak dodaje Syryjczyk, takie przesunięcie akcentów nie oznacza pominięcia pozostałych celów kary. Nie można bowiem mówić o poprawie sprawcy, jeśli nie chce on naprawić zgorszenia i wyrównać naruszonej sprawiedliwości ${ }^{9}$.

\section{Realizacja celów kary}

Normy zapisanej w kanonie 1341 KPK nie wolno odbierać jako zachęty do obojętności wobec popełnionego przestępstwa czy pasywności w przywróceniu sprawiedliwości lub pomocy wiernym w powrocie na drogę nawrócenia i zbawienia. Problematyczne może być rozeznanie drogi, którą należy podążać dla wyeliminowania konsekwencji czynu przestępczego. Droga karania jest jedną z wielu i czasami nienajlepszą. Dlatego też kan. $1341 \mathrm{KPK}$ precyzyjnie wskazuje możliwość wyboru innych dróg.

Ustawodawca najpierw zachęca do wyboru drogi ojcowskiego spotkania i dialogu (correctio fraterna), a nie karnego środka zaradczego (correptio), co może zostać określone jako „ścieżka bądź metoda pastoralna”. Taki pierwszy krok jest postrzegany jako substytut prawa karnego. W konsekwencji środki pastoralne zawierają

\footnotetext{
${ }^{7}$ Por. V. De Paolis, dz. cyt., s. 365.

${ }^{8}$ Por. J. Syry JCzy K, Kanoniczne prawo karne. Czesść ogólna. Komentarz, Warszawa 2008, s. 259.

${ }^{9}$ Por. TenżE, Niektóre gwarancje sprawiedliwego wymiaru kar w Kodeksie prawa kanonicznego z 1983 r., w: Prawo Kanoniczne 34(1991) nr 3-4, s. 157.
} 
wszystkie metody dla osiągnięcia celów, dla których ścieżka karna jest skonstruowana, jednakże pozostają poza krokiem karnym. Jeśli cele kary mogą zostać osiągnięte wystarczająco - nie mówi się lepiej albo podobnie do karnej procedury - wtedy można, a nawet w pewnym sensie należy odstąpić od drogi karania ${ }^{10}$.

Podobny pogląd reprezentuje Green. Autor w komentarzu do kan. 1341 KPK zauważa, że kar w Kościele nie można traktować jako celu samego w sobie. Powinny być one stosowane dla rozwiązania problematycznych sytuacji jako ostatni środek po środkach pastoralnych. Kościelna władza nie powinna stosować kar zbyt szybko, lecz raczej przed nałożeniem kary winna odwoływać się do wszystkich możliwych nie karnych prawno-pastoralnych opcji. Według przywołanego autora, pomiędzy tymi opcjami są: środki karne i pokuty, tradycyjne środki moralne, takie jak: rekolekcje, ojcowskie upomnienie, kuracje w specjalistycznym centrum rehabilitacyjnym. Według Syryjczyka, prawodawca wśród środków pozakarnych - o których jest mowa w kan. $1341 \mathrm{KPK}$ - nie przewiduje możliwości udzielenia upomnienia kanonicznego. Wymienia jedynie upomnienie braterskie - inne od upomnienia kanonicznego ${ }^{11}$. Dzieje się tak dlatego, że upomnienie zawarte jest już w naruszonej ustawie karnej. Pawluk do powyższych środków dodaje życzliwy dialog i perswazję ${ }^{12}$.

Kompetentny ordynariusz, w sytuacji kiedy istnieje możliwość osiągnięcia celów kary środkami pozakarnymi, nie ma obowiązku wszczynania postępowania karnego dla stwierdzenia kary zaciągniętej przez przestępcę ipso facto ${ }^{13}$. Według Pawluka, jest bezcelowe i niehumanitarne wszczynanie postępowania celem stwierdzania

\footnotetext{
${ }^{10}$ Por. V. De PaOlis, dz. cyt., s. 366.

${ }^{11}$ Por. J. Syry JCzy K, Kanoniczne prawo karne..., dz. cyt., s. 259.

${ }^{12}$ Por. T. Pawluk, Prawo kanoniczne według Kodeksu Jana Pawła II, t. 4. Doczesne dobra Kościoła, Sankcje w Kościele, Procesy, Olsztyn 1990, s. 102.

${ }^{13}$ Zgodnie z kan. $1314 \mathrm{KPK}$, kara wiążąca mocą samego prawa jest zaciągana przez sam fakt popełnienia przestępstwa, jeśli to wyraźnie postanawia ustawa lub nakaz. Zob. J. KRUкоWsкi, Kara kościelna w ogólności, w: W. Wójcik, J. Krukowski, F. Lempa, Komentarz do kodeksu prawa kanonicznego, t. 4. Dobra doczesne, Sankcje w Kościele, Lublin 1987, s. 189-191; P. M. GaJdA, Sankcje karne w Kościele
} 
kary latae sententiae, jeśli osoba, która ją zaciągnęła, poprawiła się i zmierza do naprawienia zła wyrządzonego czynem przestępczym ${ }^{14}$.

Zdaniem Syryjczyka, owe sposoby oddziaływania na przestępcę można porównać do środków zabezpieczających, a nie kar w sensie ścisłym. Nie mogą one jednak stanowić zamiennika kary ${ }^{15}$. Dopiero gdy zawiodą inne środki mające pomóc winnemu naprawić zgorszenie, wyrównać naruszoną sprawiedliwość i doprowadzić do poprawy - należy wymierzyć karę drogą procesu administracyjnego lub karnego ${ }^{16}$. Gdy proceduralne postępowanie będzie wskazane, troska o dobro duchowe osób, domniemanego sprawcy i ofiary, powinna być pastoralnym priorytetem ${ }^{17}$.

\section{Decyzja ordynariusza}

Zgodnie z decyzją najwyższego prawodawcy, ordynariusz dokonuje oceny, czy zastosowane środki pozakarne wystarczająco osiągnęły cele właściwe karom kościelnym. Jeśli okażą się niewystarczające, ordynariusz zobowiązany jest wszcząć postępowanie karne dla wymierzenia lub deklaracji kary. Należy jednak pamiętać o konieczności dania czasu przestępcy, aby mógł on naprawić zgorszenie, wyrównać naruszoną sprawiedliwość, a zwłaszcza, aby mógł się poprawić ${ }^{18}$.

Decyzja ordynariusza o odstąpieniu od drogi postępowania karnego musi opierać się na przesłankach obiektywnych. Ordynariuszowi przy podjęciu decyzji powinno towarzyszyć przekonanie o wystarczalności środków pozakarnych do osiągnięcia celów kary. Za decyzją muszą przemawiać konkretne okoliczności. Są nimi przede wszystkim: skrucha obwinionego, połączona z przyznaniem się do

w świetle Kodeksu prawa kanonicznego Jana Pawła II oraz późniejszych zmian i uzupetnień, Tarnów 2008, s. 46-47.

${ }^{14}$ Por. T. Pawluk, dz. cyt., s. 102.

${ }^{15}$ Por. J. Syry JCzy K, Kanoniczne prawo karne..., dz. cyt., s. 259.

${ }^{16}$ Por. Tenże, Niektóre gwarancje..., dz. cyt., s. 158.

${ }^{17}$ T. J. Green, Sanction in the Church, w: J. P. Beal, J. A. Coriden, T. J. Green, New Commentary on the Code of Canon Law, New York 2000, s. 1560-1561.

${ }^{18}$ Por. J. Syryjczy K, Kanoniczne prawo karne..., dz. cyt., s. 259-260. 
winy oraz pragnienie naprawienia zgorszenia i popełnionego zła (por. kan. $1347 \$ 2$ KPK) $)^{19}$.

Podejmując decyzję o odstąpieniu od drogi procesu karnego, należy jednak pamiętać, że środki pozakarne mogą okazać się niewystarczające, jeśli za karą przemawia ciężar przestępstwa oraz zasada słuszności i sprawiedliwości, rozpatrzona w kontekście potrzeby społecznej ${ }^{20}$. Mniej formalna od postępowania karnego droga pastoralna może się okazać niewystarczająca w przypadku wpłynięcia do ordynariusza zawiadomienia o popełnieniu ciężkiego przestępstwa ${ }^{21}$. Tak też się dzieje w przypadku przestępstw zarezerwowanych Kongregacji Nauki Wiary. Za każdym razem, gdy ordynariusz otrzymuje wiadomość, przynajmniej prawdopodobną, o najcięższym przestępstwie, po przeprowadzeniu wstępnego dochodzenia musi powiadomić o tym Kongregację Nauki Wiary. Jest zobowiązany także do podporządkowania się poleceniom dykasterii ${ }^{22}$.

\footnotetext{
${ }^{19}$ Por. T. Pawluk, dz. cyt., s. 102.

${ }^{20}$ Por. TAMżE, s. 102.

${ }^{21}$ P. Vere, M. Trueman, Surprised by Canon Law, t. 2. More Questions Catholics Ask About Canon Law, Cincinnati 2007, s. 103.

${ }^{22}$ Por. Joannes Paulus II, Litterae apostolicae motu proprio datae "Sacramentorum Sanctitatis Tutela" quibus Normae de gravioribus delictis Congregationi pro Doctrina Fidei reservatis promulgantur, 30.04.2001, AAS 93(2001), s. 737-739; CONGREGATIO PRo Doctrina Fidei, Epistula a Congregatione pro Doctrina Fidei missa ad totius Catholicae Ecclesiae Episcopos aliosque Ordinarios et Hierarchas quorum interest: de delictis gravioribus eidem Congregationi pro Doctrina Fidei reservatis, AAS 93(2001), s. 737-739; Normy postępowania w wypadkach ciężkich przestępstw zarezerwowanych do osadu przez Kongregację Nauki Wiary, zatwierdzone przez Benedykta XVI 21 maja 2010 r., art. 16, L’Osservatore Romano, ed. polacca, 10(2010), s. 53-56. (dalej jako: Normae); Congregation for the Doctrine of the FAith, Letter to the bishops of the Catholic Church and to the Ordinaries and Hierarchs, regarding the modifications introduced in the Normae de gravioribus delictis, 21.05.2010, w: http://www.vatican.va/resources/resources_lettera-modifiche_en.html (stan z dn. 07.11.2013).
} 


\section{Przedawnienie}

$\mathrm{Na}$ to, że dany czyn nie będzie ukarany na drodze postępowania procesu karnego bądź administracyjnego - może wpłynąć fakt przedawnienia skargi karnej. Przedawnienie skargi karnej, względnie ścigania karnego oznacza: wygaśnięcie prawa karania przestępcy ze względu na upływ ustawowo określonego czasu od chwili popełnienia przestępstwa, co powoduje, iż nie można wszcząć postępowania karnego $^{23}$. Według Syryjczyka, dłuższy upływ czasu po popełnieniu przestępstwa zaciera konieczność reakcji karnej. Natomiast ze społecznego punktu widzenia czas przynosi zapomnienie doznanej krzywdy, przebaczenie winy i traci na sile pragnienie odpłaty. Zdaniem kanonisty, karanie przestępstw po latach byłoby aktem bezwzględnego i bezcelowego odwetu, a także mogłoby wywołać ujemne skutki społeczne w postaci zgorszenia wiernych ${ }^{24}$.

Zgodnie z normą zapisaną w kan. $1362 \$ 1$ KPK: Skarga karna wygasa na skutek przedawnienia po upływie trzech lat, chyba że chodzi: $1^{\circ}$ o przestępstwa zarezerwowane Kongregacji Nauki Wiary; $2^{\circ}$ o skargę z tytułu przestępstw, o których w kan. 1394, 1395 (w przypadku przestępstw, o których jest mowa w kan. 1395 KPK, należy uwzględnić zmiany prawa dokonane przez ustawodawcę wraz ogłoszeniem Norm postępowania w wypadkach cięzkkich przestępstw zarezerwowanych do osądu przez Kongregację Nauki Wiary), 1397, 1398, która przedawnia się po upływie pięciolecia ${ }^{25} ; 3^{\circ}$ o przestępstwa,

\footnotetext{
${ }^{23}$ Por. J. SyryjCzy K, Kanoniczne prawo karne..., dz. cyt., s. 319.

${ }^{24}$ Por. TAmże, s. 321.

${ }^{25}$ Kan. 1394 KPK - duchowny oraz zakonnik ślubów wieczystych, który nie jest duchownym, usiłujący zawrzeć małżeństwo, choćby tylko cywilne. Kan. 1395 KPK - Duchowny konkubinariusz poza wypadkiem, o którym w kan. 1394, oraz duchowny trwający w innym grzechu zewnętrznym przeciwko szóstemu przykazaniu Dekalogu, wywołującym zgorszenie. Duchowny, który w inny sposób wykroczył przeciwko szóstemu przykazaniu Dekalogu, jeśli jest to połączone z użyciem przymusu lub gróźb, albo publicznie lub z osobą małoletnią poniżej lat szesnastu. Kan. 1397 KPK - osoba, która popełnia zabójstwo albo siłą lub podstępem porywa lub zatrzymuje człowieka, bądź go okalecza czy poważnie rani. Kan. 1398 KPK osoba, która powoduje przerwanie ciąży.
} 
które nie są karane prawem powszechnym, jeśli prawo partykularne ustanowiło inny termin przedawnienia.

Kongregacja Nauki Wiary, zgodnie z normą art. 52. konstytucji apostolskiej Pastor bonus, osądza przestępstwa przeciw wierze oraz najcięższe przestępstwa popełnione contra mores lub przy sprawowaniu sakramentów ${ }^{26}$. Przestępstwami przeciw wierze, są: herezja, apostazja i schizma (por. kan. 751, 1364 KPK, Normae art. 2 \$1). Najcięższymi przestępstwami przeciw świętości Najświętszej Ofiary i sakramentu Eucharystii, osądzanymi przez Kongregację Nauki Wiary są: zabranie lub przechowywanie postaci konsekrowanych w celach świętokradczych albo ich profanacja (por. kan. 1367 KPK); usiłowanie sprawowania liturgicznej czynności Ofiary Eucharystycznej (por. kan. $1378 \$ 2$, n. 1 KPK); symulacja sprawowania liturgicznej czynności Ofiary Eucharystycznej (por. kan. 1379 KPK); koncelebrowanie Ofiary Eucharystycznej z szafarzami wspólnot kościelnych nie mających sukcesji apostolskiej i nie uznających godności sakramentalnej święceń kapłańskich (por. kan. 908, 1365 KPK). Tylko Kongregacja Nauki Wiary osądza przestępstwo polegające na konsekracji w celu świętokradczym jednej tylko postaci, albo obu, podczas sprawowania Eucharystii, lub poza nią (Normae art. 3). Przestępstwami przeciw świętości sakramentu pokuty, które osądza Kongregacja Nauki Wiary, są: rozgrzeszenie wspólnika w grzechu przeciw szóstemu przykazaniu Dekalogu (por. kan. 1378 \$1 KPK); usiłowanie udzielenia rozgrzeszenia sakramentalnego albo słuchanie spowiedzi pomimo zakazu (por. kan. $1378 \$ 2$, n. 2 KPK); symulowanie udzielania rozgrzeszenia sakramentalnego (por. kan. 1379 KPK); nakłanianie do grzechu przeciw szóstemu przykazaniu Dekalogu w akcie spowiedzi albo przy jej okazji lub pod jej pretekstem, jeśli ma na celu grzech z samym spowiednikiem (por. kan. $1387 \mathrm{KPK}$ ); bezpośrednie lub pośrednie naruszenie tajemnicy sakramentalnej (por. kan. $1388 \$ 1 \mathrm{KPK}$ ). Do kompetencji Kongregacji Nauki Wiary należy także osądzanie przestępstwa polegającego na nagrywaniu za pomocą jakichkolwiek

\footnotetext{
${ }^{26}$ Por. Ioannis Pauli II, Constitutio apostolica de Romana Curia. Pastor Bonus, art. 52, 28.06.1988, AAS 80(1988), s. 874.
} 
urządzeń technicznych albo na rozpowszechnianiu w złych zamiarach w środkach społecznego przekazu tego, co zostało powiedziane przez spowiednika lub penitenta w spowiedzi sakramentalnej, prawdziwej lub fałszywej (Normae art. 4).

Dykasteria osądza również przestępstwo usiłowania udzielenia sakramentu święceń kobiecie (Normae art. 5).

Najcięższymi przestępstwami przeciw obyczajom, które osądza tylko Kongregacja Nauki Wiary, są: przestępstwo przeciw szóstemu przykazaniu Dekalogu popełnione przez duchownego z nieletnim poniżej osiemnastego roku życia oraz z osobą, która trwale jest niezdolna posługiwać się rozumem; nabywanie albo przechowywanie lub rozpowszechnianie w celach lubieżnych materiałów pornograficznych, przedstawiających nieletnich poniżej czternastego roku życia, przez duchownego - w jakikolwiek sposób i za pomocą jakiegokolwiek urządzenia (Normae art. 6).

Ogłoszone przez Kongregację Nauki Wiary normy dotyczące delicta graviora - jako prawo specjalne spowodowało zmiany prawa promulgowanego przez Jana Pawła II w kodeksie z 1983 roku. Zmianie uległa między innymi kwalifikacja niektórych czynów przestępczych oraz długości czasu przedawnienia. Podczas gdy w kan. $1395 \$ 2 \mathrm{KPK}$ mowa jest o przestępstwie „Z osobą małoletnią poniżej lat szesnastu”, to $\mathrm{w}$ przywołanym dokumencie o "przestępstwie z osobą małoletnią poniżej lat osiemnastu”. Stąd też klasyfikacja przestępstwa staje się bardziej złożona ${ }^{27}$.

Zgodnie z art. 17 norm dotyczących delicta graviora, skarga karna odnośnie do przypadków przestępstw osądzanych tylko przez Kongregację Nauki Wiary wygasa na skutek przedawnienia dopiero po upływie dwudziestu lat, a nie jak stanowił KPK dziesięciu lat. Zgodnie z normą zamieszczoną w kan. $1362 \$ 2 \mathrm{KPK}$, przedawnienie liczy się od dnia popełnienia przestępstwa lub, jeśli przestępstwo jest permanentne bądź habitualne, od dnia jego ustania. Od tej zasady jest jednak

\footnotetext{
${ }^{27}$ Por. C. J. Scicluna, Procedura i Zasady postępowania Kongregacji Nauki Wiary dotyczace delicta graviora. Promotor Sprawiedliwości (Kongregacja Nauki Wiary 2004), s. 4.
} 
wyjątek. Zachodzi on w przypadku przestępstwa przeciw szóstemu przykazaniu Dekalogu popełnionego przez duchownego z nieletnim poniżej osiemnastego roku życia. W tej sytuacji przedawnienie zaczyna się liczyć od dnia, w którym nieletni skończył osiemnaście lat.

Dykasteria ma również prawo uchylania przedawnienia w poszczególnych przypadkach (por. Normae art. 7).

\section{Podsumowanie}

Intencją ustawodawcy jest, by stosowanie kar w Kościele było zjawiskiem rzadkim. Zanim przystąpi się do ukarania przestępcy, należy wyczerpać wszelkie inne środki natury duszpasterskiej czy prawnej ${ }^{28}$. Dzieje się tak dlatego, że cała działalność Kościoła powinna być podporządkowana najwyższej zasadzie wyrażonej w ostatnim kanonie Kodeksu prawa kanonicznego. Według niej, zbawienie dusz winno być zawsze w Kościele najwyższym prawem (por. kan. $1752 \mathrm{KPK}$ ). Jak zauważa Pastuszko, w realizacji tego celu - jakim jest zbawienie dusz - muszą uczestniczyć wszyscy, którzy działają w imieniu Kościoła. Oznacza to, że wszystkie urzędy w Kościele mają wymiar duszpasterski. Każda czynność podejmowana przez osoby, którym został powierzony urząd kościelny, musi w dalszej perspektywie prowadzić do uświęcenia i zbawienia ${ }^{29}$. Zdaniem autora, ordynariusz - odpowiedzialny za karność kościelną w powierzonej mu wspólnocie - musi być rzecznikiem prawa kościelnego pojętego teologicznie, a nie tylko formalnie ${ }^{30}$. Nawet decyzja o wszczęciu postępowania karnego na drodze procesowej lub administracyjnej ma pomóc oskarżonemu wejść na drogę zbawienia ${ }^{31}$. Ratio legis normy zapisanej w kan. 1341

\footnotetext{
${ }^{28}$ Por. M. FĄKA, Nowe kanoniczne prawo karne, w: Duszpasterstwo..., dz. cyt., s. 249.

${ }^{29}$ Por. T. Pawluk, dz. cyt., s. 101.

${ }^{30}$ Por. TAmże, s. 101.

${ }^{31}$ Por. F. Nigro, De sanctionibus in Ecclesia, w: Studium Romanae Rote. Corpus Iuris Canonici. I. Commento al Codice di Diritto Canonico, red. P. V. Pinto, Libreria Editrice Vaticana 2001, s. 792.
} 
KPK znalazło swój oddźwięk w kan. $1718 \$ 1$ n. 2 KPK oraz 1344 n. 2 $\mathrm{KPK}^{32}$.

Kończąc rozważania, należy również odnotować fakt, że doniesienie ewangeliczne (por. Mt 18, 15-19) do ordynariusza, mające przede wszystkim na celu doprowadzenie do poprawy przestępcy, nie stanowi podstawy wszczęcia dochodzenia wstępnego, o którym mowa w kan. 1717 KPK. W takiej sytuacji powiadamiający ordynariusza traktuje przestępcę jak brata, a ordynariusza jak ojca, który ma zatroszczyć się o poprawę przestępcy. Warunkiem wszczęcia dochodzenia wstępnego jest doniesienie sądowe uczynione przez osobę prywatną bądź publiczną, jeżeli jego celem jest ukaranie sprawcy czynu, który przynajmniej prawdopodobnie nosi znamiona przestępstwa ${ }^{33}$.

$\mathrm{Z}$ uwagi na przedawnienie skargi kryminalnej, wymiar kary w wielu wypadkach może być również niemożliwy.

\section{Does one always have to initiate a judicial or administrative proceedings after obtaining information of possibility of committing crime to execute a penalty sanction?}

The intention of the legislator is to apply penalties in the Church as rarely as possible. Before instigating the punishment for the criminal, one should use all other means of pastoral or legal nature. This is because the entire activity of the Church should be subordinated to the highest principle stated in the final canon of the Canon Law. According to it, the salvation of souls must always be the supreme law in the Church (can. 1755 CIC). The ordinary, who is responsible for the discipline in the community entrusted to him, must advocate for the rights of the canon law theologically, not only

\footnotetext{
${ }^{32}$ Kan. 1718 \$1 KPK: Kiedy elementy wydają się wystarczająco zebrane, ordynariusz winien zadecydować: $1^{\circ}$ czy może być wszczęty proces w celu wymierzenia albo deklarowania kary; $2^{\circ}$ czy to, biorąc pod uwagę kan. 1341, jest wskazane (...) Kan. 1344 KPK: Chociaż ustawa używa słów nakazujących, sędzia zgodnie z własnym sumieniem i roztropnością może: $2^{\circ}$ powstrzymać się od wymierzenia kary lub wymierzyć karę mniejszą albo zastosować pokutę, jeśli winny się poprawił i naprawił zgorszenie (...).

${ }^{33}$ Por. J. Krukowski, Proces Karny, w: Komentarz do Kodeksu prawa kanonicznego, t. 5. Księga VII, Procesy, red. J. Krukowski, Poznań 2007, s. 402.
} 
formally. Even the decision on the initiation of the criminal proceedings on the criminal or administrative way, is to help the accused to enter the path of salvation. Due to prescription a criminal action, in many cases the application of penalty is impossible.

SŁOWA KLUCzOWE: wszczęcie postępowania karnego, kara, przedawnienie.

KEY WORDS: initiation of the criminal proceedings, penalty, prescription.

\section{Nota o Autorze:}

DR ToMAsz JAKUBIAK - pracownik naukowo-dydaktyczny Papieskiego Wydziału Teologicznego w Warszawie, Sekcja św. Jana Chrzciciela; adiunkt. 